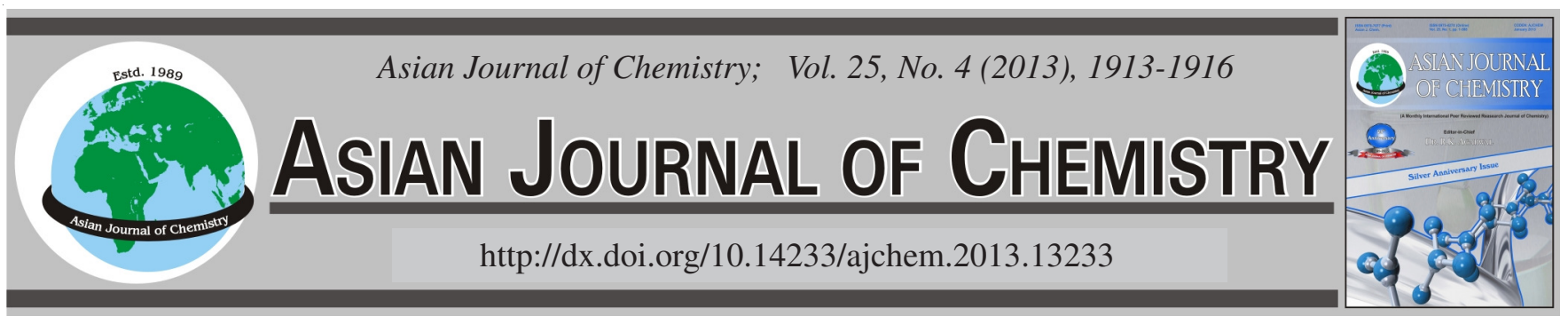

\title{
Synthesis, Crystal Structure and Antibacterial Activity of Ca(II) Complex with 2-(Phenylsulfonamido)acetic Acid
}

\author{
TAi XI-ShI ${ }^{*}$, Chu SI-YuAn and TANG ChUn-YING
}

College of Chemistry and Chemical Engineering, Weifang University, Weifang 261061, P.R. China

*Corresponding author: Fax: +86 536 8785363; Tel: +86 536 8785363; E-mail: taixs@wfu.edu.cn

\begin{abstract}
A new ligand 2-(phenylsulfonamido)acetic acid (L) and its $\mathrm{Ca}$ (II) complex have been synthesized and characterized by elemental analysis, IR spectroscopy and single-crystal X-ray diffraction. The results showed that the complex formed one dimensional chained structure through intramolecule and intermolecule hydrogen bonds and $\pi$ - $\pi$ stacking. The antibacterial assay of the $\mathrm{Ca}(\mathrm{II}) \mathrm{complex}$ and the lignd $\mathrm{L}$ was tested using a modified version of 2-fold serial dilution method. The $\mathrm{Ca}$ (II) complex shows considerable antibacterial activity against Escherichia coli, Bacillus subtilis and Staphylococcus white.

Key Words: 2-(Phenylsulfonamido)acetic acid, Ca(II) complex, Crystal structure, Antibacterial activity.

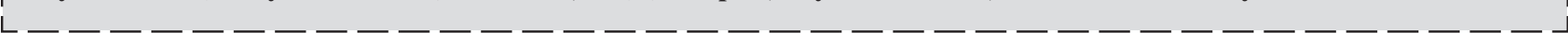

\section{INTRODUCTION}

Calcium is the indispensable element in biology. It is involved in several biochemical processes and is the essential cofactor required for the activation of a variety of enzymes. In the process of metabolism, calcium ions possess of a variety of coordination structures and play an important role in catalysis. It can be as the enzyme activator and bridged the adjacent carboxylates to strengthen the cell membrane in the lipoprotein $^{1-3}$. In eucaryotes, calcium ions are involved in regulation of dozens of processes, such as mitosis, muscle contraction, proliferation and coagulation of blood, hormone secretion and differentiation in different types of cells. In addition, it also plays an integrating role in controlling coordinated function of different compartments, cells and organs. Thus, it is referred to the metal of life ${ }^{4-6}$. It is significant to study ${ }^{7}$ on the structure and characteristic coordination of calcium for making sure about physiological and biochemical mechanisms of all lives.

Aromatic compounds with carboxylic acid are affluent in the coordination structures ${ }^{8,9}$, their complexes are important for academic significance, but also possess potential application and prospect in many areas, such as material, biochemistry, medicinal preparation, catalytic behavior, micro-porosity, electrical conductivity, non-linear optical activity and cooperative magnetic behavior ${ }^{10-14}$. Herein, a novel calcium complex was synthesized by the reaction of calcium perchlorate tetrahydrate with 2-(phenylsulfonamido)acetic acid and was characterized by X-ray single crystal diffraction, indicating that the complex formed one-dimensional chain structure. The antibacterial assay of the $\mathrm{Ca}$ (II) complex was tested using a modified version of the 2-fold serial dilution method.

\section{EXPERIMENTAL}

The following AR grade chemicals were used for the preparation of the studied compound: calcium perchlorate tetrahydrate, benzenesulfonyl chloride, glycine, sodium hydroxide.

The carbon, hydrogen and nitrogen content in the newly synthesized compound were determined on a Elementar Vario III EL elemental analyzer. Infrared spectrum (4000-400 $\mathrm{cm}^{-1}$ ) was recorded with $\mathrm{KBr}$ optics on a Nicolet AVATAR 360 FTIR spectrophotometer. The crystal data was collected on a Bruker smart CCD Area Detector.

Synthesis of the ligand: $10 \mathrm{mmol}(0.7507 \mathrm{~g})$ of glycine and $20 \mathrm{mmol}(0.8 \mathrm{~g})$ of sodium hydroxide were dissolved in $100 \mathrm{~mL}$ of water at room temperature and added drop by drop $10 \mathrm{mmol}(1.7662 \mathrm{~g})$ of benzenesulfonyl chloride by stirring at room temperature. The reaction solution was kept running for $4 \mathrm{~h}$, then acidified with the solution of hydrochloric acid (v:v $=1: 1)$ to $\mathrm{pH}=2$. The white solid precipitation were collected by filtration, washed and dried under vacuum. Yield may reach up to over $65 \%$. Elementary analysis: calcd. (\%) for $\mathrm{C}_{8} \mathrm{H}_{9} \mathrm{NSO}_{4}$ : C, 44.65; H, 4.19; N, 6.51; found (\%): C, 44.58; $\mathrm{H}, 4.52 ; \mathrm{N}, 6.59$. IR $\left(\mathrm{KBr}, \mathrm{v}_{\max }, \mathrm{cm}^{-1}\right):(\mathrm{C}=\mathrm{O}): 1718$, $(\mathrm{N}-\mathrm{H})$ : 3248 (Fig. 1). 


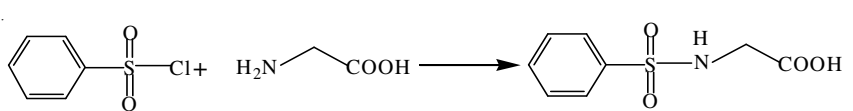

Fig. 1. Synthesis and structure of 2-(phenylsulfonamido)acetic acid

Synthesis of Ca(II) complex: $1 \mathrm{mmol}(0.215 \mathrm{~g})$ of 2-(phenylsulfonamido)acetic acid and $1 \mathrm{mmol}(0.04 \mathrm{~g})$ of sodium hydroxide were added to the $10 \mathrm{~mL}$ of $\mathrm{CH}_{3} \mathrm{OH} / \mathrm{H}_{2} \mathrm{O}$ $(\mathrm{v}: \mathrm{v}=2: 1)$ solution. After being dissolved, $0.5 \mathrm{mmol}(0.138 \mathrm{~g})$ of calcium perchlorate tetrahydrate was added to the solution. The mixture was continuously stirred for $3 \mathrm{~h}$ at refluxing temperature. The mixture was cooled at room temperature and was collected by filtration. By evaporation in air at room temperature, the single crystal suitable for X-ray determination was obtained from methanol solution after 10 days. Yield: $56 \%$. Elementary analysis: calcd. (\%) for $\mathrm{C}_{24} \mathrm{H}_{24} \mathrm{~N}_{3} \mathrm{O}_{12} \mathrm{~S}_{3} \mathrm{CaNa}$ : C, 40.85; H, 3.43; N, 5.95; found (\%): C, 40.58; H, 3.69; N, 5.72. IR $\left(\mathrm{KBr}, v_{\max }, \mathrm{cm}^{-1}\right):(\mathrm{C}=\mathrm{O}): 1677,(\mathrm{~N}-\mathrm{H}): 3248,\left(\mathrm{H}_{2} \mathrm{O}\right): 3423$.

X-Ray crystallography: A colourless block single crystal with dimensions of $0.49 \mathrm{~mm} \times 0.46 \mathrm{~mm} \times 0.40 \mathrm{~mm}$ was placed on a glass fiber and mounted on a CCD area detector. Diffraction data were collected by $\phi \sim \omega$ scan mode using a graphitemonochromatic $\mathrm{MoK}_{\alpha}$ radiation $(\lambda=0.71073 \AA$ ) at 298 (2) $\mathrm{K}$. A total of 14432 reflections were collected in the range $1.39-25.01^{\circ}$, of which 5190 were unique $\left(R_{\text {int }}=0.045\right)$ and 3866 were observed with $\mathrm{I}>2 \sigma(\mathrm{I})$. The data were corrected for $\mathrm{Lp}$ factors. The structure was solved by direct methods and refined by full-matrix least-squares techniques on $\mathrm{F}^{2}$. The structure was solved by direct methods ${ }^{15}$ using SHELXL-97 and expanded using Fourier techniques. All non-hydrogen atoms and hydrogen atoms were refined anisotropically and isotropically, respectively. The final refinement by fullmatrix least squares method was converged at $\mathrm{R}=0.041$ and $\mathrm{wR}=0.1166\left(\mathrm{w}=1 /\left[\delta^{2}\left(\mathrm{Fo}^{2}\right)+(0.0507 \mathrm{P})^{2}+2.4758 \mathrm{P}\right], \mathrm{P}=\right.$ $\left.\left(\mathrm{Fo}^{2}+2 \mathrm{Fc}^{2}\right) / 3, \mathrm{~S}=1.055,(\Delta / \sigma)_{\max }=0.001\right)$. The largest peak in the final difference Fourier map is $0.512 \mathrm{e} / \AA^{3}$ and the minimum peak is $-0.513 \mathrm{e} / \AA^{3}$. Molecular graphics were drawn with the program package SHELXTL-97 crystallographic software package $^{16}$. The most relevant crystal data for complex are quoted in Table-1 and the selected bond distances and angles are listed in Table- 2 .

Antibacterial assay: The ligand and the complex were dissolved in sterile water and tested against three reference strains for antibacterial activity, respectively. The antibacterial assay was performed using a modified version of the 2-fold serial dilution method ${ }^{17}$, in which the concentration of compounds decreased half as many in a sterile culture medium containing broth as the nutrient and the strains were incubated $16 \mathrm{~h}$ in the culture mediums at the constant temperatures $37^{\circ} \mathrm{C}$ after being activated and misce bene after being added to the test tubes of chemical medicine, then readings were taken after $24 \mathrm{~h}$ of incubation at the constant temperatures $37^{\circ} \mathrm{C}$. All other test conditions were standardized. The resultant turbidities in all tubes were estimated visually and the lowest drug concentrations were found, which is defined minimum inhibitory concentration (MIC). After $48 \mathrm{~h}$ of continuous incubation, the minimum bacterial concentration (MBC) was defined, too.
TABLE- 1 CRYSTALLOGRAPHIC DATA FOR Ca(II) COMPLEX

\begin{tabular}{ll}
\hline Formula & $\mathrm{C}_{24} \mathrm{H}_{24} \mathrm{~N}_{3} \mathrm{O}_{12} \mathrm{~S}_{3} \mathrm{CaNa}$ \\
Formula weight & 705.71 \\
Crystal system & Monoclinic \\
Space group & $\mathrm{P}_{1} / \mathrm{n}$ \\
$\mathrm{a}(\AA)$ & $17.406(2)$ \\
$\mathrm{b}(\AA)$ & $8.7089(10)$ \\
$\mathrm{c}(\AA)$ & $20.069(3)$ \\
$\alpha\left({ }^{\circ}\right)$ & 90.00 \\
$\beta\left({ }^{\circ}\right)$ & $104.088(2)$ \\
$\gamma\left({ }^{\circ}\right)$ & 90.00 \\
$\mathrm{Z}$ & 4 \\
$\mathrm{~F}_{\text {(o00) }}$ & 1456 \\
Temperature $(\mathrm{K})$ & $298(2)$ \\
$\mathrm{V}\left(\AA^{3}\right)$ & $2950.8(6)$ \\
Calculated density $\left(\mathrm{g} \mathrm{cm}{ }^{-3}\right)$ & 1.589 \\
Crystal size $\left.(\mathrm{mm})^{3}\right)$ & $0.49 \times 0.46 \times 0.40$ \\
$\mu\left(\mathrm{mm}^{-1}\right)$ & 0.507 \\
Limiting indices & $-16 \leq \mathrm{h} \leq 20,-10 \leq \mathrm{k} \leq 8$, \\
& $-23 \leq 1 \leq 23$ \\
Reflections collected / unique & $5190 / 3866$ \\
$\mathrm{R}_{1}, \mathrm{wR}_{2}$ [all data] & $0.0621,0.1166$ \\
$\mathrm{R}_{1}, \mathrm{wR}_{2}[\mathrm{I}>2 \sigma(\mathrm{I})]$ & $0.0405,0.0989$ \\
Largest diff. peak and hole $\left(\mathrm{e} \AA^{-3}\right)$ & $0.512,-0.513$ \\
\hline
\end{tabular}

\begin{tabular}{|c|c|c|c|}
\hline \multicolumn{4}{|c|}{$\begin{array}{c}\text { TABLE-2 } \\
\text { SELECTED BOND LENGTHS }(\AA) \text { AND } \\
\text { ANGLES }\left({ }^{\circ}\right) \text { FOR Ca(II) COMPLEX }\end{array}$} \\
\hline $\mathrm{Ca} 1-\mathrm{O} 10^{\mathrm{i}}$ & $2.322(2)$ & $\mathrm{Na} 1-\mathrm{O} 7^{\mathrm{iii}}$ & $2.377(2)$ \\
\hline Ca1-O9 & $2.323(2)$ & $\mathrm{Na}-\mathrm{O} 3^{\text {iv }}$ & $2.403(2)$ \\
\hline $\mathrm{Ca} 1-\mathrm{O} 2^{\mathrm{i}}$ & $2.339(2)$ & Na1-O1 & $2.412(2)$ \\
\hline Ca1-O6 ${ }^{\mathrm{ii}}$ & $2.362(2)$ & $\mathrm{Na} 1-\mathrm{O} 4^{\mathrm{v}}$ & $2.413(2)$ \\
\hline Ca1-O1 & $2.402(2)$ & $\mathrm{Na} 1-\mathrm{O} 8^{\mathrm{vi}}$ & $2.447(2)$ \\
\hline Ca1-O5 & $2.435(2)$ & $\mathrm{Na1-O5}$ & $2.456(2)$ \\
\hline O10-Ca1-O9 & $162.14(8)$ & $\mathrm{O} 7^{\mathrm{iii}}-\mathrm{Na} 1-\mathrm{O} 3^{\mathrm{iv}}$ & $84.60(9)$ \\
\hline 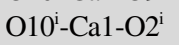 & $81.60(8)$ & $\mathrm{O} 7^{\mathrm{iii}}-\mathrm{Na} 1-\mathrm{O} 1$ & $97.56(8)$ \\
\hline O9-Ca1-O2 & $80.91(8)$ & $\mathrm{O}^{\mathrm{iv}}-\mathrm{Na} 1-\mathrm{O} 1$ & $165.63(9)$ \\
\hline $\mathrm{O} 10^{\mathrm{i}}-\mathrm{Ca} 1-\mathrm{O} 6^{\mathrm{ii}}$ & $92.07(9)$ & $\mathrm{O} 7^{\mathrm{iii}}-\mathrm{Na} 1-\mathrm{O} 4^{\mathrm{v}}$ & $83.47(9)$ \\
\hline O9-Ca1-O6 ${ }^{\mathrm{ii}}$ & $82.15(8)$ & $\mathrm{O} 3^{\mathrm{iv}}-\mathrm{Na} 1-\mathrm{O} 4^{\mathrm{v}}$ & $106.60(9)$ \\
\hline $\mathrm{O}^{\mathrm{i}}-\mathrm{Ca} 1-\mathrm{O}^{\mathrm{ii}}$ & $82.73(8)$ & $\mathrm{O} 1-\mathrm{Na} 1-\mathrm{O} 4^{\mathrm{v}}$ & $87.77(9)$ \\
\hline O10-Ca1-O1 & $88.51(8)$ & $\mathrm{O} 7^{\mathrm{iii}}-\mathrm{Na} 1-\mathrm{O} 8^{\mathrm{vi}}$ & $101.33(9)$ \\
\hline O9-Ca1-O1 & $108.77(8)$ & $\mathrm{O} 3^{\mathrm{iv}}-\mathrm{Na} 1-\mathrm{O} 8^{\mathrm{vi}}$ & $81.34(9)$ \\
\hline $\mathrm{O} 22^{\mathrm{i}}-\mathrm{Ca} 1-\mathrm{O} 1$ & $169.79(8)$ & O1-Na1-O8 ${ }^{\mathrm{vi}}$ & $84.30(8)$ \\
\hline O66-Ca1-O1 & $95.17(7)$ & $\mathrm{O} 4^{\mathrm{v}}-\mathrm{Na} 1-\mathrm{O} 8^{\mathrm{vi}}$ & $171.20(10)$ \\
\hline O10'-Ca1-O5 & $105.54(8)$ & O7 ${ }^{\text {iii-Na1-O5 }}$ & $163.22(9)$ \\
\hline O9-Ca1-O5 & $82.97(8)$ & $\mathrm{O}^{\mathrm{iv}}-\mathrm{Na} 1-\mathrm{O} 5$ & $103.79(8)$ \\
\hline $\mathrm{O} 22^{\mathrm{i}-\mathrm{Ca} 1-\mathrm{O} 5}$ & $106.45(8)$ & O1-Na1-O5 & $77.97(7)$ \\
\hline $\mathrm{O}^{\mathrm{ii}-\mathrm{Ca} 1-\mathrm{O} 5}$ & $161.02(8)$ & $\mathrm{O} 4^{\mathrm{v}}-\mathrm{Na} 1-\mathrm{O} 5$ & $80.22(8)$ \\
\hline O1-Ca1-O5 & $78.57(7)$ & $\mathrm{O}^{\mathrm{vi}}{ }^{-\mathrm{Na} 1-\mathrm{O} 5}$ & $94.36(9)$ \\
\hline
\end{tabular}

Symmetry codes: (i) $-x+1 / 2, y+1 / 2,-z+1 / 2$; (ii) $-x+1 / 2, y-1 / 2,-z+1 / 2$; (iii) $-\mathrm{x},-\mathrm{y}+1,-\mathrm{z}$; (iv) $-\mathrm{x},-\mathrm{y},-\mathrm{z}$; (v) $\mathrm{x}, \mathrm{y}+1, \mathrm{z}$; (vi) $\mathrm{x}, \mathrm{y}-1, \mathrm{z}$.

\section{RESULTS AND DISCUSSION}

IR spectra: In the infrared spectra, the $\mathrm{v}(\mathrm{COOH})$ vibration of the free ligand are at $1718 \mathrm{~cm}^{-1}$. For the complex, the vibration was shifted to $1677 \mathrm{~cm}^{-1}$, which can be explained that the carboxylate oxygen atoms of 2-(phenylsulfonamido) acetic acid ligand are involved in the coordination with calcium atoms as bridging didentate ${ }^{18}$. The bands of the $-\mathrm{SO}_{2}-\mathrm{NH}-$ groups at 3248, 1320 and $1155 \mathrm{~cm}^{-1}$ show that there are uncoordinated atoms of the groups, because compared with the free ligand the strong absorption bands are not shifted. In addition, the band at $3423 \mathrm{~cm}^{-1}$ shows that the complex contains water 
molecules, which are in accordance with the results of elemental analysis.

Structure description: Perspective view of the molecule in a unit cell and molecular packing arrangement are shown in Figs. 2 and 3, respectively. It can be seen that the coordination environment of the $\mathrm{Ca}$ (II) atom consists of three oxygen atoms from the three 2-(phenylsulfonamido)acetic acid ligands and three oxygen atoms from the coordinated water molecules, making up a distorted octahedral environment. The coordination atoms $(\mathrm{O}(5), \mathrm{O}(6), \mathrm{O}(9), \mathrm{O}(10))$ are situated equatorial place and the coordination atoms $(\mathrm{O}(1), \mathrm{O}(2))$ are situated axial place. In the complex molecule, the $\mathrm{Na}$ (II) atom coordinates with two oxygen atoms from the two carboxylato group of two 2-(phenylsulfonamido)acetic acid ligands, one oxygen atom of $\mathrm{S}=\mathrm{O}$ group and three oxygen atoms from the coordinated water molecules, also making up a distorted octahedral environment. The coordination atoms $(\mathrm{O}(1), \mathrm{O}(3), \mathrm{O}(4), \mathrm{O}(8))$ are situated equatorial place and the coordination atoms $(\mathrm{O}(5)$, $\mathrm{O}(7))$ are situated axial place. The distances of the $\mathrm{Ca}(1)-\mathrm{O}$ bonds are in the range of 2.322(2) 2 - 2.435(2) $\AA$, which are similar to the $\mathrm{Ca}-\mathrm{O}$ bond lengths reported previously ${ }^{19}$.

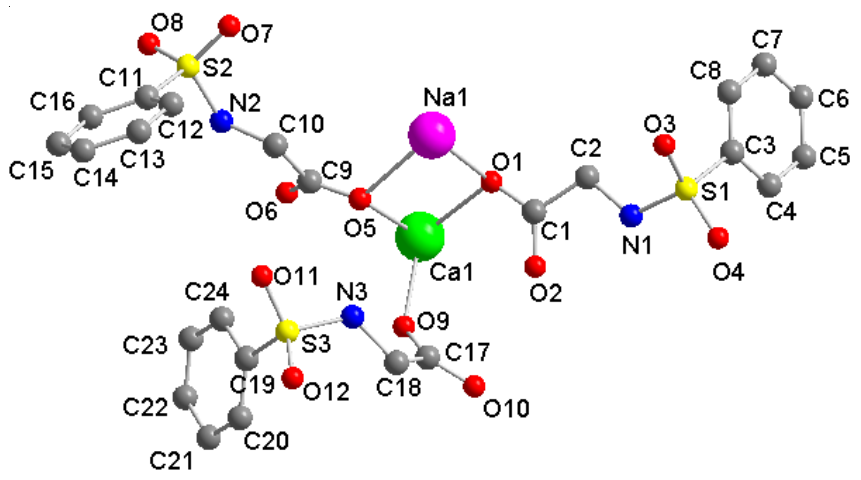

Fig. 2. Molecular structure of the complex, where the thermal ellipsoids were drawn at $30 \%$ possibility. Ca-Na distance is $3.7567(11) \AA$

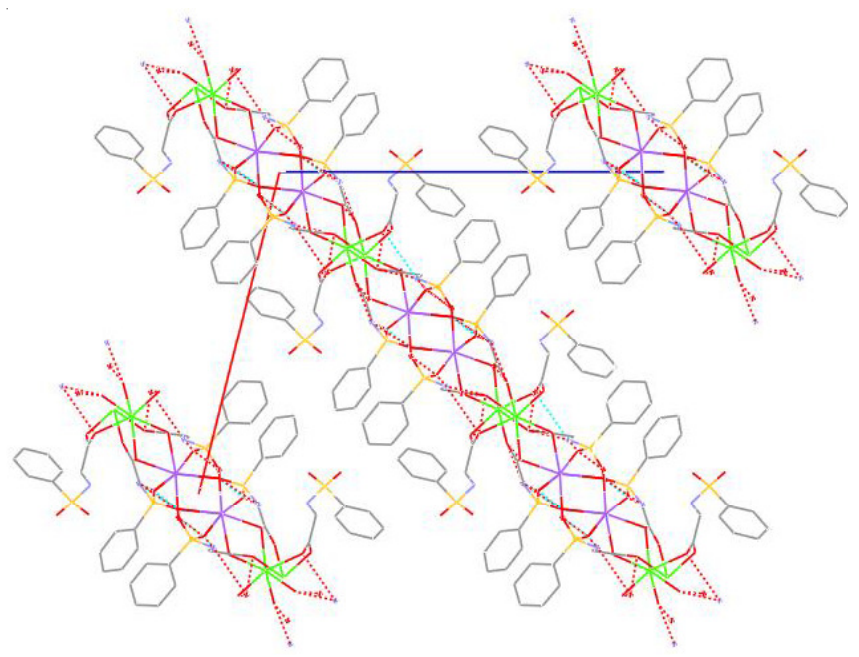

Fig. 3. One dimensional chain of the complex

The complex forms one dimensional chain structure along the $b$ axis by intramolecule and intermolecule hydrogen bonds and $\pi-\pi$ stacking. The coordination polyhedron of $\mathrm{Ca}$ and $\mathrm{Na}$ atoms in the complex and the 2D infinite net structure of complex viewed down the a axis is shown in Fig. 4.

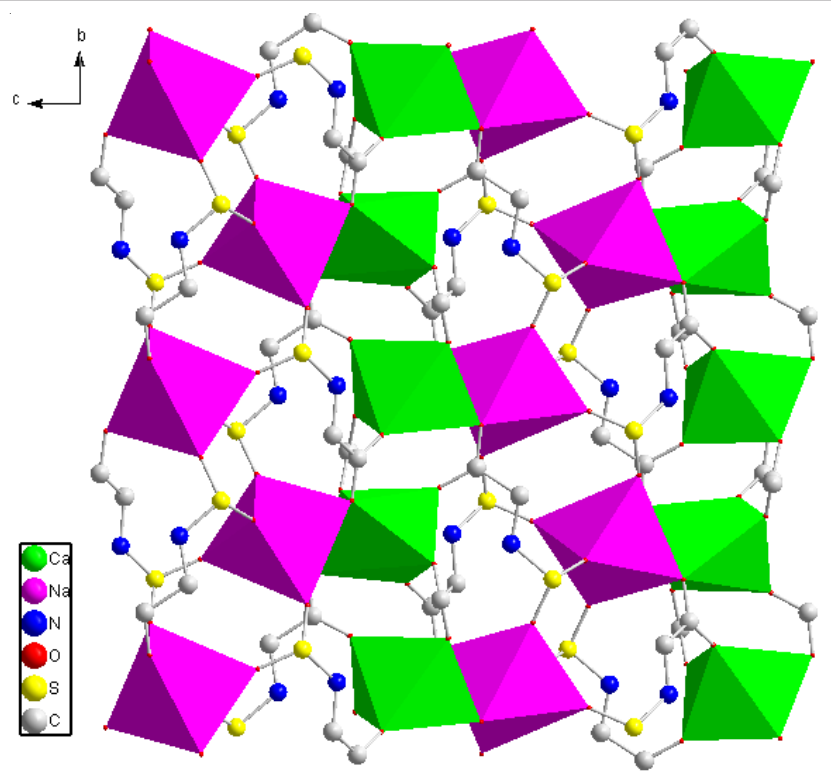

Fig. 4. Coordination polyhedron of $\mathrm{Ca}$ and $\mathrm{Na}$ atoms in the complex, and the $2 \mathrm{D}$ infinite net structure of complex viewed down the a axis. Hydrogen atoms and phenyl groups are omitted for clarity

Antibacterial activity: The antibacterial activity of the 2-(phenylsulfonamido)acetic acid ligand and $\mathrm{Ca}(\mathrm{II})$ complex were assayed using three bacterial strains (Escherichia coli, Bacillus subtilis and Staphylococcus white). The antibacterial results of the complex are listed in Table-3 and the results indicate that the $\mathrm{Ca}(\mathrm{II})$ complex shows considerable antibacterial activity. Compared with the complex, the N-2-(phenylsulfonamido)acetic acid ligand did not show antibacterial activity. So the complex will provide potential applications in the broad spectrum of the antibacterial field.

\begin{tabular}{lcc}
\multicolumn{3}{c}{ TABLE-3 } \\
\multicolumn{3}{c}{ MIC AND MBC OF COMPLEX AGAINST } \\
& THREE BACTERIAL STRAINS \\
\hline \multicolumn{1}{c}{ Strains } & MIC $(\mathrm{mg} / \mathrm{mL})$ & MBC $(\mathrm{mg} / \mathrm{mL})$ \\
\hline Escherichia coli & 0.675 & 0.675 \\
Bacillus subtilis & 0.675 & 1.250 \\
Staphylococcus white & 0.625 & 0.625 \\
\hline MIC: Minimal inhibitory concentration. & & \\
concentration. & & \\
\hline
\end{tabular}

\section{Conclusion}

In summary, a novel $\mathrm{Ca}$ (II) complex has been synthesized and structurally characterized. The $\mathrm{Ca}(\mathrm{II})$ ion is coordinated by three oxygen atoms from the three 2-(phenylsulfonamido) acetic acid ligands and three oxygen atoms from the coordinated water molecules. The antibacterial activity of the $\mathrm{Ca}(\mathrm{II})$ complex indicates that the $\mathrm{Ca}$ (II) complex shows considerable antibacterial activity against Escherichia coli, Bacillus subtilis and Staphylococcus white.

\section{ACKNOWLEDGEMENTS}

The authors would like to thank the National Natural Science Foundation of China (No. 21171132 and 20671073), the Promotive Research Fund for Excellent Young and Middleaged Scientisits of Shandong Province (2010BSA07004) and Science Foundation of Weifang University. 


\section{REFERENCES}

1. X.S. Tai, Y.M. Feng, F.Y. Kong, D.Q. Wang and M.Y. Tan, Chin. J. Inorg. Chem., 24, 831 (2008).

2. Y. Su, S.Q. Zang, C.L. Ni, Y. Z. Li and Q.J. Meng, Chin. J. Inorg. Chem., 20, 845 (2004).

3. S. Gao, Z.Y. Zhang, L.H. Huo, H. Zhao and J.G. Zahao, Chin. J. Inorg. Chem., 21, 771 (2005).

4. Y. Lu, G.C. Deng, F.M. Miao and Z.M. Li, J. Inorg. Biochem., 96, 487 (2003).

5. S.M. Avaeva, N.N. Vorobyeva, S.A. Kurilova, T.I. Nazarova, K.M. Polyakov, E.V. Rodina and V.R. Samygina, Biochemistry, 65, 442 (2000).

6. X.S. Tai, J. Yin, Y.M. Feng and F.Y. Kong, Chin. J. Inorg. Chem., 23, 1812 (2007)

7. W.K. Cao, S.X. He, J.S. Zhao, R. Yang, Q.Z. Shi, D.Q. Wang and J.M. Dou, Acta Chim. Sin., 61, 1612 (2003).

8. B. Chen, M. Eddaoudi, S.T. Hyde, M.O'Keeffe and O.M. Yaghi, Science, 291, 1021 (2001).

9. S.F. Brady and J. Clardy, J. Am. Chem. Soc., 122, 12903 (2000)
10. B. Zhao, P. Cheng, X.X. Chen, C. Cheng, W. Shi, D.Z. Liao, S.P. Yan and Z.H. Jiang, J. Am. Chem. Soc., 126, 3012 (2004).

11. Y.Y. Yang, M.H. Zeng, S.H. Zhang and H. Liang, Struct. Chem., 19, 771 (2008).

12. B.S. Haman and S. Sagdinc, Struct. Chem., 19, 381 (2008).

13. L.J. Tian, H.J. Yang, X.L. Zheng, Z.H. Ni, D.M. Yan, L.L. Tu and J.Z. Jiang, Appl. Organometal. Chem., 23, 24 (2009).

14. Y.H. Wen, X. Feng, Y.L. Feng, Y.Z. Lan and Y.G. Yao, Inorg. Chem. Commun., 11, 659 (2008).

15. G.M. Sheldrick, SHELXL-97, Program for Crystal Structure Solution; University of GÖttingen: GÖttingen, Germany (1997).

16. G.M. Sheldrick, SHELXTL-97, Program for Crystal Structure Solution; University of GÖttingen: GÖttingen, Germany (1997).

17. J.L. Zhou, Q.S. Yao and H. Xu, Chin. J. Modern Appl. Pharm., 17, 148 (2000).

18. K. Nakamoto, Infrared and Ramen Spectra of Inorganic and Coordination Compounds, New York: John Wiley and Sons, American, edn. 3 (1978).

19. X.S. Tai, Adv. Mater. Res., 282-283, 108 (2011). 